\title{
The Idea of Higher Education as a Citizen's Constitutional Right: A Comparative Study
}

\author{
Fitra Arsil ${ }^{1}$, Qurrata Ayuni² \\ \{Fitra.arsil@ui.ac.id ${ }^{1}$, qurrataayuni@ui.ac.id²\} \\ Faculty of Law, Universitas Indonesia, Depok ${ }^{1}$, Faculty of Law, Universitas \\ Indonesia, Depok ${ }^{2}$
}

\begin{abstract}
The construction in the Indonesian Constitution requires primary education as a constitutional right for citizens. This clause can be found in Article 31 of the 1945 Constitution, which states that "every citizen is obliged to attend basic education and the government is obliged to finance it". However, the comparative study in this paper finds that many other countries affirm the obligation of higher education as a citizen's right. Formulation regarding higher education in the world's Constitution is interesting for two reasons; First, there is a state priority in human resource development through higher education. Second, there is a constitutional awareness to place higher education as an inherent constitutional right for citizens. Using a normative juridical method with a comparative approach, this paper finds that at least 22 countries include higher education clauses in their constitutions. This indicates the progressivity of legal politics in favor of the progress of education in respective countries.
\end{abstract}

Keywords: higher education; right to education; constitutional right

\section{Introduction}

Plato in The Republic said that the purpose of education cannot be separated from the goals of the state (Turan, 2011). According to him, education is a means to achieve a just and happy people. Understanding the important role of education, almost all countries include a clause on state responsibility in fulfilling basic education (Imber et al., 2013). However, only about 22 countries include the word higher education in their constitutions.

The development of advanced education courses of action in the Indonesian Constitution is exceptional. Article 31 section (2) of the 1945 Constitution obliges each resident to go to primary education. The Indonesian Constitution likewise necessitates that the financial education plan is focused on no less than a fifth of the state income and consumption financial plan and the local income and use financial plan to address the issues of the public instruction organization.

Most of the world's nations incorporate a proviso in regards to the commitment of the state to give the satisfaction of the right to education to citizens. This arrangement in the Constitution has three essential implications; first, as constitutional legitimacy, the imposition of state responsibility as a fundamental thing that must be carried out. Second, it provides a control design for budget allocation and state policies related to education. Third, as a form of social engineering or social reform in engineering, the formation of society (Asshiddiqie, 2010). 
The obligation to fulfill education can also be seen in the context of fulfilling human rights (Cisse et al., 2012). Article 26 of the Universal Declaration of Human Rights emphasizes the importance of fulfilling human rights, namely the right to education. Furthermore, it was also emphasized that there is a directive to place education in developing recognition and respect for human rights(Isa \& de Feyter, 2009). Countries that have ratified the United Nations Covenant on Economic, Social, and Cultural Rights have also given a further burden to realize by fulfilling free basic education. Moreover, Article 13 of the ratification of the United Nations Covenant on Economic, Social, and Cultural Rights includes provisions that emphasize efforts to provide free higher education in stages.

The authors found a typology of approaches in each of the constitutions of the world's countries related to higher education through a comparative study. The first is countries that provide arrangements regarding equal rights to obtain higher education for all their citizens. Second are countries that offer the approach to autonomous freedom. The third is countries that provide funding arrangements and mandates to free higher education.

The three regulatory typologies in the constitutions of these countries will be discussed in detail in the next section. The affirmation of the clause regarding higher education has not appeared in the Indonesian Constitution either before or after the amendment. However, in efforts to develop human resources in the era of globalization, the idea of including the importance of higher education may be worth considering. Not only to ensure the quality of human resources for the fourth largest population in the world but also to welcome the development of a better country. To borrow Nelson Mandela's quote, "No country can develop unless its citizens are educated."

\section{Results and Discussions}

\subsection{Equal Rights of Higher Education}

Understanding the right to education as a human right may constitute a consensus in the DUHR. In particular, Article 26 of the DUHR emphasizes every country to give the right to education for every citizen at the level of basic education. Basic education, according to the UDHR, is mandatory. In simple terms, this concept provides a minimal index of what is meant by fulfilling the right to education.

However, the influence of security stability, economic level, and welfare level affect the success of a country in fulfilling the right to education. So that both the quality and quantity in the fulfillment of the fundamental right to education can vary widely. At this level, the guarantee of the fulfillment of the right to education becomes very fragile to be influenced by factors of stability and welfare of a country.

The context of guaranteeing the fundamental right to education in the Constitution is easy to find in the constitutions of world countries (Brooks-Gordon et al., 2007). However, a number of countries have written higher education in the Constitution to provide increased responsibility for education. UDHR gives a mandate for each country to guarantee accessibility and equal rights to get higher education for all citizens (Albi \& Bardutzky, 2019). This is what the author found in several constitutions in the world, namely the Constitution of Portugal, Constitution of Moldova, Constitution of Lithuania, Constitution of Hungary, Constitution of Slovakia, Constitution of Croatia, Constitution Ghana, Lesotho Constitution, and Kazakhstan Constitution. 
Strictly speaking, for example, Article 76 of the Portuguese Constitution guarantees democratic access to higher education. This means that every Portuguese Government is obliged to ensure equal opportunities in the education system for every individual citizen. The quality education and scientific culture, of course, accompany this. Another constitution, Article 35 of the Moldovan Constitution, guarantees that higher education is mandatory for everyone to access. The same narrative can also be found in Article 30 of Kazakhstan, Ghana, which provides equal rights to participate in higher education, of course, based on competition and competence.

The comparison that the author draws on in this paper basically cannot conclude whether the fulfillment of the right to higher education in these countries has been going well. This is because the context of the implementation and implementation of the fulfillment of the right to higher education may not explicitly be found in the Constitution. However, in many cases, different countries establish specific laws on higher education at various levels. For example, like Indonesia, although it does not include a clause on higher education in the 1945 Constitution, it has specifically Law Number 12 of 2012 concerning Higher Education.

\subsection{Higher Education Autonomy}

The concept of higher education autonomy is a form of academic freedom that must be owned by an educational institution(Shattock, 2014). Educational institutions such as higher education must be given a space to think critically and analytically in a democratic environment. The teaching and learning process in the world of higher education cannot be separated from the freedom of research, publication of research results, and censorship. The doctrine of the regime basically does not match that habitat.

Academic freedom as a part of the reason for the autonomy of higher education is one of the important elements also written in the Constitution. In addition, several world constitutions such as the Constitution of Moldova, the Constitution of Bulgaria, the Constitution of Poland, the Constitution of Albania, the Constitution of Turkey, and the Constitution of Finland guarantee higher education autonomy in their constitutions.

The importance of higher education in the development of a country is guaranteed through academic freedom in the country's constitutions. For example, Article 35 of the Constitution of Moldova and Article 53 of Bulgaria state that higher education should enjoy the right to autonomy. Likewise, in Article 70 of the Polish Constitution, there must be the protection of autonomy based on a special statute for higher education. Again, article 57 of the Albanian Constitution provides guarantees by law for the autonomy and academic freedom of higher education. However, of all the constitutions, perhaps the Turkish Constitution is the most detailed Constitution regarding granting higher education autonomy. Article 130 of the Constitution subtleties that the conceding of self-governance is given to instructing, allocated to teach, train at various levels after optional schooling, direct exploration, go about as experts, issue distributions, and serve the nation and humankind.

The urgency of autonomy for higher education, especially in the history of the Indonesian Constitution, is actually very important to be adopted. It is considering a number of events involving university students in the formation of the Republic of Indonesia as well as in the process of amending the 1945 Constitution. The role of the student movement, which is part of higher education in Indonesia, can be found in the history of the 1960s and 1998, which brought about new changes in reform and democracy in Indonesia. This is a clear example of academic freedom and autonomy in higher education, which should also be adopted in the Indonesian Constitution. 


\subsection{Higher Education Funding}

International conventions and declarations have previously emphasized the obligation to fulfill basic education for citizens. This is indicated by the financing obligations stated in the Constitution. Therefore, as a basis for the formation of laws and regulations, the existence of a financing clause becomes a concrete norm that can no longer be negotiated to be reduced at the level of budget policy. So that the presence of a clause in the Constitution regarding funding for higher education makes guaranteeing the continuity and sustainability of education a priority in fulfilling the constitutional rights of citizens (John \& Parsons, 2005).

Several countries that have clauses that provide free education for basic education are already very numerous. Indonesia is also an example of a country that allocates $20 \%$ of the state budget and regional budgets for education, especially basic education. But, unfortunately, special allocations and clauses to waive fees for citizens pursuing higher education are not guaranteed in the Indonesian Constitution.

The Bulgarian Constitution, Russian Constitution, Ukrainian Constitution, Luxembourg Constitution, Belarus Constitution, and Sri Lanka Constitution provide funding clauses and exemptions from higher education fees. For instance, Article 53 of the Constitution of Ukraine expresses that each resident has the privilege to acquire free advanced education in the state and common instructive organizations on a cutthroat premise. Then, at that point, Article 43 of The Constitution Of The Russian Federation expresses that everybody has the privilege to get seriously free advanced education at a state or instructive civil organization. A similar provision can also be found in the Belarusian Constitution, which states that special secondary education and higher education must be accessible to everyone according to their respective abilities in state educational institutions free of charge.

Various aspects of the budget and funding in the Constitution are usually only explicitly listed for the most fundamental things. Placing a budget clause or a free provision in the Constitution guarantees that citizens' fulfillment is more secure. On the other hand, it imposes a very rigid state budget obligation specifically for the education sector.

\subsection{Law on Higher Education in Indonesia}

Although it does not include a higher education clause in the Constitution, Indonesia basically has a law that regulates higher education. Indonesia has Law No. 12 of 2012 concerning Higher Education. It was clarified that advanced education as a component of the public training framework plays an essential part in teaching the country's life and propelling science and innovation by focusing on and applying humanities esteems just as supportable enlightening and strengthening of the Indonesian nation.

In particular, Article 8 of the Higher Education Law provides guarantees and autonomy for higher education. It is clarified that the execution of scholarly opportunity, an opportunity of the scholastic podium, and logical self-rule in Higher Education is the moral obligation of the Academic Civitas, which should be ensured and worked with by the administration of the Higher Education. It is additionally clarified that what is implied by logical self-rule is the self-governance of the Academic Civitas is a part of science or potentially innovation in finding, creating, unveiling, and additionally keeping up with logical truth as per rules, logical strategies, and scholastic culture. 
Although it does not explicitly talk about the amount of budget that must be issued each year, the Higher Education Law also provides a clause regarding the obligation to provide funds for higher education. Article 83 of the Higher Education Law states that the Government offers Higher Education funds which are allocated in the State Revenue and Expenditure Budget. Furthermore, the Regional Government can support Higher Education funds allocated in the Regional Revenue and Expenditure Budget.

The Higher Education Law also confirms the guarantee of equal rights with the principle of non-discrimination. Furthermore, article 6 expresses that the focal point of advanced education is completed equitably and decently and isn't prejudicial by maintaining common freedoms, strict qualities, social qualities, pluralism, solidarity, and public solidarity. So basically, this article provides a guarantee for granting the right to education at the level of the law.

\section{Conclusion}

The world's constitutional arrangements have further regulated higher education in its Constitution. Several similarities were found in the formulation of the clauses in these constitutions, namely; First, the guarantee of equal rights in accessing higher education for all citizens. Second, there is a guarantee of educational autonomy and academic freedom for higher education. Third, there is a free budget allocation or guarantee for higher education.

Through this comparison, it can be concluded that including higher education in the constitutional clause confirms that a country is paying more attention to improving the quality of human resources through education. Second, there is awareness to guarantee higher education as the fulfillment of the right to more advanced education as part of the constitutional rights of citizens.

The idea of placing a regulation regarding higher education in the Constitution in Indonesia, namely the 1945 Constitution, is fascinating. This is done to provide constitutional guarantees for citizens to improve the quality of human resources and the competence of future generations of the nation so that the security of access to higher education for all Indonesian citizens can be guaranteed.

\section{References}

[1] Albi, A., \& Bardutzky, S.: National Constitutions in European and Global Governance: Democracy, Rights, the Rule of Law: National Reports (2019). T.M.C. Asser Press. https://books.google.co.id/books?id=186aDwAAQBAJ

[2] Asshiddiqie, J.: Konstitusi dan konstitusionalisme Indonesia. Sinar Grafika (2010). https://books.google.co.id/books?id=WzAbcgAACAAJ

[3] Brooks-Gordon, B., Barak-Erez, D., Gross, A. M., Ebtehaj, F., Herring, J., Johnson, M., \& Richards, M.: Exploring Social Rights: Between Theory and Practice. Hart (2007). https://books.google.co.id/books?id=E6zcvQEACAAJ

[4] Cisse, H., Muller, S., Chenguang, W., \& Thomas, C.: The World Bank Legal Review: Legal Innovation and Empowerment for Development. World Bank Publications (2012). https://books.google.co.id/books?id=MBtR2haM4mMC

[5] Imber, M., Van Geel, T., Blokhuis, J. C., \& Feldman, J.: Education Law. Routledge (2013). https://books.google.co.id/books?id=BwtVmgEACAAJ 
[6] Isa, F. G., \& de Feyter, K.: International Human Rights Law in a Global Context. Universidad de Deusto (2009). https://books.google.co.id/books?id=9WxePwAACAAJ

[7] John, E. P. S., \& Parsons, M. D.: Public Funding of Higher Education: Changing Contexts and New Rationales. Johns Hopkins University Press (2005). https://books.google.co.id/books?id=859znEJfLaAC

[8] Shattock, M.: International Trends in University Governance: Autonomy, self-government and the distribution of authority. Taylor \& Francis (2014). https://books.google.co.id/books?id=bqbAAwAAQBAJ

[9] Turan, S.: Plato' s Concept of Education in 'Republic' and Aristotle' s Concept of Education in ' Politics ' Plato' nun ' Cumhuriyet' ve Aristo' nun ' Politika ' Adl1 Eserlerinde Eğitim Kavramı (2011). 